\title{
Bearing of Training on Employee Performance: Evidence from the Banking Sector in India
}

\author{
Dr. Manodip Ray Chaudhuri \\ Associate Professor and Dean \\ Xavier Business School \\ St. Xavier's University, Kolkata, India
}

(Graduate Alumnus, University of Guelph, Ontario, Canada)

\&

Mr. Parth Mehra

Recruitment Associate

Byju's, Kolkata, India

Email; myhrm05@yahoo.co.in

\begin{abstract}
Training is an important part of an organization and no one can think of development without it. By training, there is an attitudinal change in the employee, that leads to positive thinking, a sense of devotion to organizational and also by the help of technical and behavioural training the person in the organization can be aware of the latest developments and know how to come up with the best output with minimum investment and minimum labour waste. Every organization should have well trained and experienced employees to perform the activities in their day to day operations. Human Resources Management regards training as the blood stream of any organization because the success of an organisation highly depends on its workforce. For this reason, organizations should invest in employees training, which in an effort to enhance the performance of the employees which directly affect the performance of the organization. Nonetheless, some organizations regard training as unnecessary expenditure and always cut budgets in an effort to improve their financial standing to the detriment of their employee's welfare, because of this action it is difficult for the staff to adapt to the ever-changing working environment and uncertain conditions with rapid technological innovation and organizational change.
\end{abstract}

Trained employees contribute to the efficiency, growth, increased productivity and market reputation of an enterprise. Organizations need to realize that and train and manage the human resource for a sustainable growth in the present uncertain environment. Past research on training and development programmes indicate that appropriate training delivery is a crucial decision, the trainers have to yield optimum result. This is realized by industrial, commercial, research establishments and also by government institutions.

In this paper, we have discussed about the training and development in the banking sector for both the private as well as public sector banks in India. HDFC Bank and ICICI Bank in the private spectrum and State Bank of India and Punjab National Bank in the public spectrum have been considered in this study. Discussion is illustrated and exemplified on how training and development initiatives are having a significant bearing on the performance of the employees, which in-turn are directly impacting the overall performance of an organization.

Keywords: training, HRM, changing working environment, efficiency, productivity, employee welfare, banks, private, public

\section{Introduction}

The world in which organizations and managers operate today would be unrecognizable to their peers 35 years ago. In other words, the way organization develops people has changed over the years. Approaches used for learning have shifted as the practice and purpose of training and developing people have grown in importance, broaden in scope and have become a more sophisticated. Training is essentially a management tool derived to foster and increase the required skills and knowledge base of employees and also employers with a view to ultimately increasing both the employees and organizations performance in terms of overall productivity. Development is a more advanced tool, essentially allows the employees to progress along a career path with the skills and knowledge they gain over time. It allows employees progress according to the needs of the organization. Latest studies have shown that organizations greatly invest in Human Resource Development so as to keep their employees updated and skilled in order to attain job performance, job satisfaction and job involvement. These skills can be conveyed by providing the necessary technical/non-technical training to the employees by analysing the current demand of skills in the market. Employee performance is an important building 
block for an organization and factors which lay the foundation for high performance must be analysed by the organizations. Performance is a major multidimensional element, aimed to achieve results and has a strong link to strategic goals of an organization.

Nowadays in India, to perform well, public sector banks and private sector banks are competing with each other. In banks, nowadays traditional HR practices are modified into innovative HR practices. In today's competitive world, to fight out the challenges from other banks, HRD department has to play important role in shaping the employees. For an organization training and development are important. Nowadays, banks are using various new channels of banking which are as follows:-

- Nowadays banks are providing ATM machines for the quick withdrawal of money.

- For the customer's help most banks are also proving call centres service.

- Banks are also proving their customers online banking facility for the transactions of money from one place to another over the internet.

- Mobile banking is also provided by the banks for banking transactions.

\section{Banking structure in India:-}

In India, all banks work under Reserve Bank of India and situated in different areas. The following are as under given:

\section{Private sector banks:-}

A private sector bank is a bank which is run or controlled by a group of people or by an individual to gain profit. Different types of private sectors banks are as follows: - Non-scheduled banks- Non-scheduled banks are those banks, which have paid a reserve capital of five lakh rupees to the Reserve Bank of India and have to keep this throughout their operational period. In India there are only four non-scheduled banks which are as follows:-

- Akhand Anand Co-operative Bank Limited

- $\quad$ Alavi Co-operative Bank Limited

- Amarnath Co-operative Bank Limited

- AmodNagrik Sahakari Bank limited

- Foreign banks- A foreign bank is that bank which follows the rules and regulations of the host countries and home countries also. The head office of a foreign bank are located outside the country.
- $\quad$ Scheduled banks- The banks which comes under the 2nd scheduled of Reserve Bank of India regulation act 1934 are known as scheduled banks.

- New generation banks- Indian government permitted new generation banks in the country and the list of such banks are as follows:

- $\quad$ HDFC Bank

- $\quad$ ICICI Bank

- YES BANK

- $\quad$ KOTAK MAHINDRA BANK

- $\quad$ AXIS BANK

- BANDHAN BANK

- INDUSIND BANK

Public sector banks:-

A public sector bank is that, which is run or controlled by the government and all the decisions are taken by the government like State Bank of India (SBI).

Now the most important question in front of the organization is how to train their employees. When it comes to specific training methods in use now, the leading ways organizations train their employees through webcasts, Web conferences, and webinars, collectively cited by 84 percent of respondents. Then comes the traditional classroom instruction which is used by around 82 percent. Self-study with books, magazines, and other no electronic means is third in the list at 70 percent. The method of training to the employees totally depends on the organization and chances depending on the number of employees to be trained at a time.

\section{Key Issues:}

It has been understood that how important training is for the employees in this dynamic business environment and why every employee should be given the chance to learn something new and implement it in their day to day life. Banking sector over the years have evolved to a great extent after the intervention of technology in the banking sector like internet banking, mobile banking and many other. People working in the banking sector need to be trained to understand this new technology and implement in their day to day operation so that they can give better service to their customers. Both private and public banks goes for training and development process of their employees, but private banks do it more seriously do 
to large competition in the sector. Training and development increases the ability, knowledge of the employees which will directly impact the performance of the organization. For this research study, four banks have been selected with two public bank and two private bank which operate in the Indian economy. These are HDFC Bank and ICICI Bank in the private sector ad SBI and PNB in the public sector of India.

The diagram below, shows us the reason why training and development is important to employees or we can say that the outcome of an effective training and development program is reflected in the performance of the employees.

\section{Purpose of the study:}

- To get an understanding of the training and development in the banking sector, both public and private bank.

- $\quad$ To get an understanding of the effect of training and development on the performance of the employees of the selected private and public bank.

- $\quad$ To get an idea of different methods used by selected private and public banks for training and development of the employees.

- To understand whether training and development as an HR initiative is an enabling factor for enhancing employee performance.

\section{Research Method:}

The data for this report has been collected from secondary sources of authentic websites, reports, journal and books. The information is collected from the Research Journals, Trade Magazines, Annual Reports of Banks and the Internet. For evaluating, The Impact of T\&D in Banking Industry, focus was recent material. In order to get access to the latest developments in this area, have used a number of articles published in academic journals and trade magazines. I have also used secondary information from Internet based discussion forums.

\section{Limitations of the study:}

- Time constrain is one of the major problem faced during the course of this study.

- Did not involve all the private and public banks in the economy; selection was done according to the convenience.

- Study is limited to the interaction done with a selected group of employees of the bank and all employees are not considered.

\section{Focal Discussion:}

In order to understand the impact of training on the employees' performance, literature has been investigated to bring to light the following understandings.

- $\quad$ Ramakrishna, Kumar, Girdhar, and Krishnudu (2012) had projected in their study that Human Resource Development has to take up the task of developing the required skills in the employees so as to face the challenges of the emerging markets. The bank
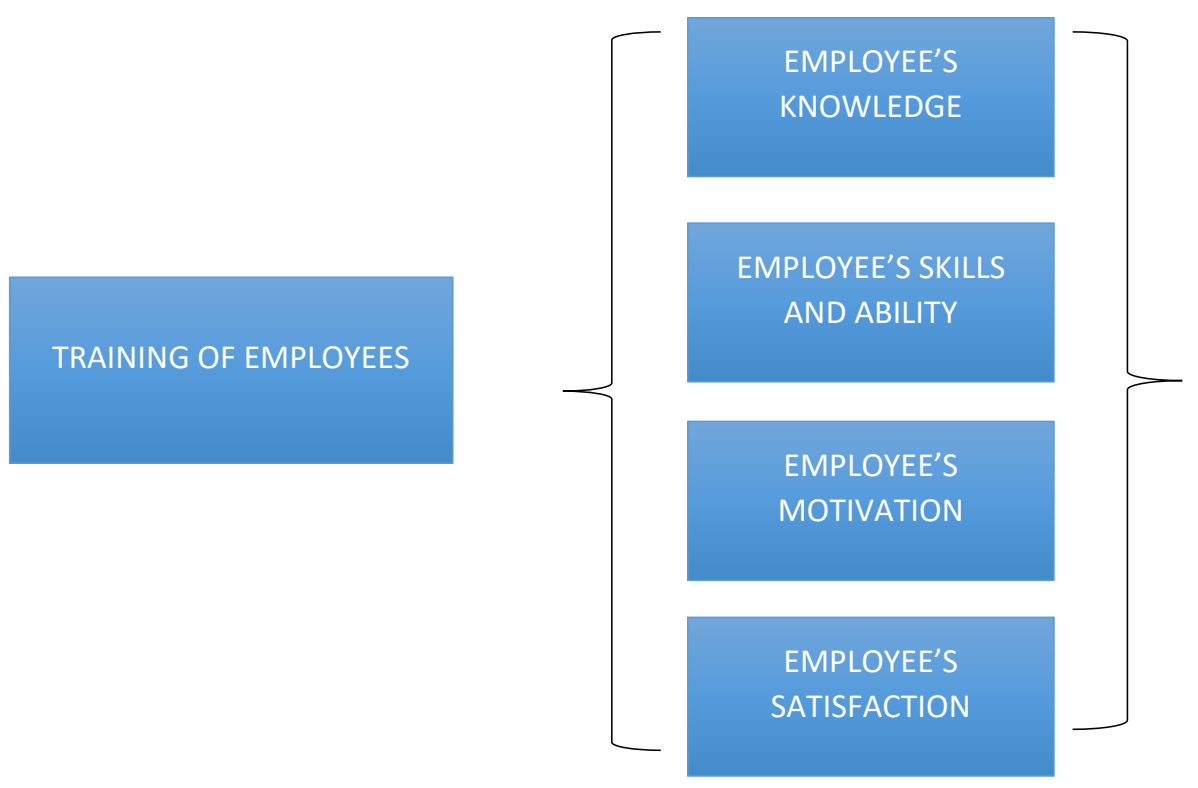

Figure 1: Effect of training on employee's performance 
management not only has to devise strategies and make plans and policies, but need to see to their implementation effectively.

- Cole (2012), in his book "Personnel and Human Resource Management", stated that training is a learning activity directed towards the acquisition of some specific knowledge and skills for the purpose of an occupation or task. For example, the need to have efficiency and safety in the operation of particular machines or equipment is very important to avoid any kind of accident in the workplace.

- Swatee Sarangi (2012) has put forth the fact that the changing regulations, highly competitive market and technological changes have forced the Banking sector in India to update and undergo changes in their day to day operations. Employee engagement is the outcome of HR researcher's dedication to retain employees and motivate them to perform well in future. The characteristics of an Engaged employee are that he/she is more profitable, productive, and retained with the company.

- Jadhav (2013) conducted a study on the training and development programmes undertaken by banks for their employees to cope up with the current economic reforms and to maintain the productivity and profitability of the organization. The main objectives of this study was to analyse the impact of training and development programmes for employees and to correlate whether the objective of achieving customer satisfaction had been met with by the employees by discharging their duties in a more effective manner after the training. For the purpose this study a sample of 40 employees was selected from prominent banks like HDFC, ICICI, Vijaya bank, Bank of Baroda, and Dena Bank which located in suburban area of Mumbai and primary data was collected through questionnaire filled by the bank employees working in these banks.

- Mahbuba Sultana (2013) highlighted that effective training increases the productivity of employees in the organization. Data for this study was collected from 1414 employees working in Dhaka. Correlation methodology was used in the research. The author concludes that employee are a valuable resource for any organization and the success and failure depends upon the performance and productivity of the employees and this study proves that the training do improves the productivity of the employees and help the organization as well.

- Zohair Abbas (2014) highlighted training as an essential element for an employee for the development of the companies because some of the employees have lack of knowledge, skills and competencies and failed to accomplish task on time. The sample has been taken from both males and female employees working in the banking sector. The research is descriptive and quantitative in nature. Primary data was collected and secondary data was also used to classify the work done. Study provides an empirical evidence of factors that effects employees training and performance in an organization.

- Angela, (2014) in her study stated that training had an impact on the performance of employee among the international civil servants. A survey research was designed and was used in this study of 144 staff of the United Nation supports office for the African mission in Somalia. The finding showed that in general, training do enhance employee engagement on change processes, motivation, job satisfaction and overall performance in employees and do have impact on their performance.

- $\quad$ Ngugi Martha Nyakeo Nyokabi (2014) stated that training plays a significant role in the development of competencies of new as well as existing employees in the organization for effective performance. Data was collected from 800 employees from company in Nairobi. This study shows how training \& development is related with employee performance. The Findings of the study shows that the training of employees is very important factors for both the organization and the employees because it enhances work performance, motivate employees and build confidence in the employees.

- Falola, Osibanjo, and Ojo, (2014) in their study revealed that there exists a strong relationship between training and development and employees performance. The summary of findings of this research work indicates that there lies strong relationship between the tested dependent variable and independent construct. However, the bank management should not cave in their quest to train the employees in order to develop new ideas that will keep improving and retain employees in the organization.

- Ampomah, (2016) in his study found that employees are aware of the purpose of training in the organization, the objectives of training are clear to them before the training begins. The study also found out that employees are motivated through training, and training and development results into higher performance of the organization.

- Jaspreetkaur (2016) in her study on a sample of 
85 employees covering all Canara bank branches in Kurnool District showed that the employees strongly agreed about the necessity of training and development programmes, they have attended more training and development programmes, majority of the employees have rated the trainer as good in respect of their presentation, they also praised the trainers for creating a learning environment and also the employees have been given overall rating for training and development programmes on the basis of their involvement in the program.

\section{Private Sector Banks considered - HDFC Bank and ICICI Bank:-}

Now the first bank in the private bank which was selected is the market leader in the private banking sector which is HDFC bank. The HDFC bank was amongst the first bank to receive an approval from the Reserve Bank of India to set up a bank in the private sector, as part of RBI's liberalisation policy of the Indian Banking Industry in 1994. The bank was incorporated in August 1994 by the name of 'HDFC Bank Limited', having its registered office in Mumbai, India. At the current state the bank has around 5103 outlets and 13160 ATMs all over India.

The above diagram shows the performance of the HDFC bank over a time span of 5 years, and we can see that the net profit after deducting the tax is increasing year after year. The main reason behind this performance is the human resource management policies and practices in HDFC bank. HDFC Bank uses a comprehensive human resources policy framework to respond the changing human resources requirements. Rapid growth in the new market should be the cause for celebration, as the organization need to survive in this competitive environment. Keeping other human resource policies aside we just focus on the training and development part of the human resource practice of the organization which HDFC took very seriously. The HDFC Bank has regularly focus on the training of its employees, which include both on the- job as well as through training programmes conducted by internal and external faculty. The Bank has made a strong training infrastructure, which helps to upgrade skill levels across grades and functions through a combination of in-house and external programmes. The bank's core career philosophy is that after hiring a conducive environment is created for employees to develop and grow. This is done through systematic investment of time in career discussion with employees, competency assessment and intensive functional and behavioural training through Gurukul - our in-house programme.

The job levels are described below:

- E3 and below: Non-supervisory staff and Sales Officers

- $\quad$ E4- D1: Junior Management

- D2-D5: Middle Management

- $\quad \mathrm{C} 1$ and above: Senior Management

- $\quad$ IBA

The other private bank which have been take for this study is ICICI bank which have a market share of $13.10 \%$. It is the 2 nd bank in terms of market capitalization in India after HDFC bank in private sector. ICICI Bank Limited is an Indian multinational banking and financial services company, which is headquartered in Mumbai, Maharashtra with its registered office in Vadodara, Gujarat. ICICI is the second largest private sector bank in India. It has a huge network of 2,528 branches and about 6,000 ATMs in India andhave a presence in around 19 countries including India. It employs around 36,000 employees.

Training and Development in ICICI Bank is done by the employees in the HR department who are responsible for such activities. Training and Development is headed by a senior-

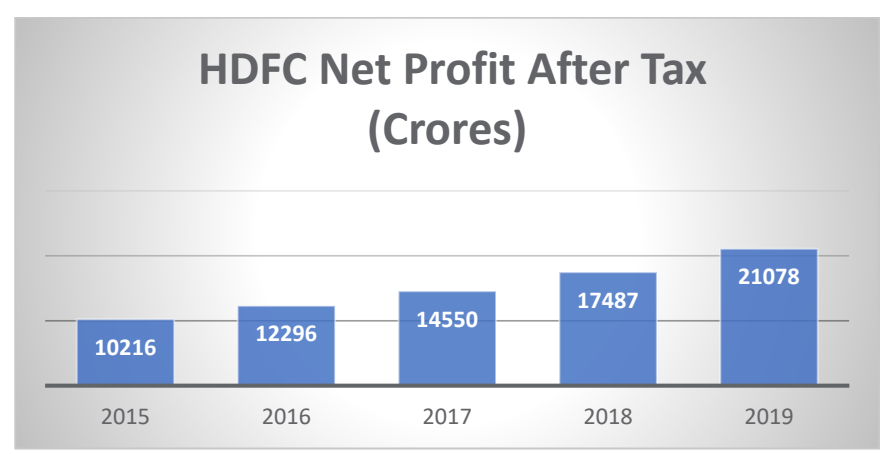

Figure 2: Net profit from 2015-2019 


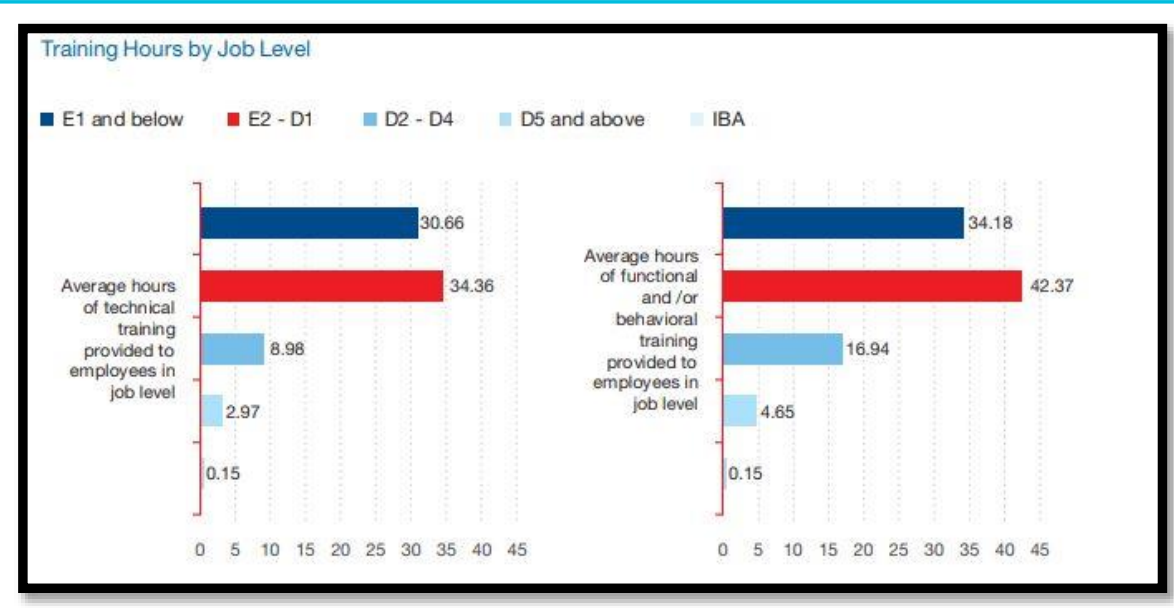

Source- hdfcbank.com

level officers. Training and Development process in ICICI bank is considered essential for the progress and growth of the bank. Since, inadequate training and employee errors constitute a major operational risk for the bank as banks deals with the money of the people. Now let's discuss the whole training and development process which takes place in ICICI bank. ICICI bank has considered two approaches for selection of learning and training method.

- Operational-Reaction decision making- This approach is used by the bank to bridge the gap in the expected levels of services expected by the bank like quality, customer service, etc. These are identified through Training need analysis, evident through feedback and data by using feedback surveys, focused managerial discussion.

- $\quad$ Strategic-Proactive Decision making- Organizations capitalize on emerging business opportunities by building their capabilities for the long term goals through training of the employees. Indian banking industry as a whole has taken this initiatives in this areas to build their capabilities.

New Initiatives taken by ICICI:
1. Winning Hearts- Winning Hearts is a video based training program, to engage with customers with sensitivity and solution oriented approach. The best practice approach customers has been designed covering various customer behaviour scenarios. The program was monitored by central head and it covered more than 1200 branch banking staff in a week.

2. Gaming and Simulation Engine- This is considered to be an innovative learning medium to skill employees on process and operation skill which need to be completed in ten weeks and an interesting part is, fresh training game is developed for every training process.

3. I-Voice- The communication with all the company stake holders of the company is transparent in ICICI bank. There is a video magazine called I-Voice which is the source of information in ICICI which is published quarterly. This video magazine is of 90 minutes duration which is screened to employees across banks through town hall meetings facilitated by senior members of bank.

Both the banks, HDFC and ICICI bank are giving their

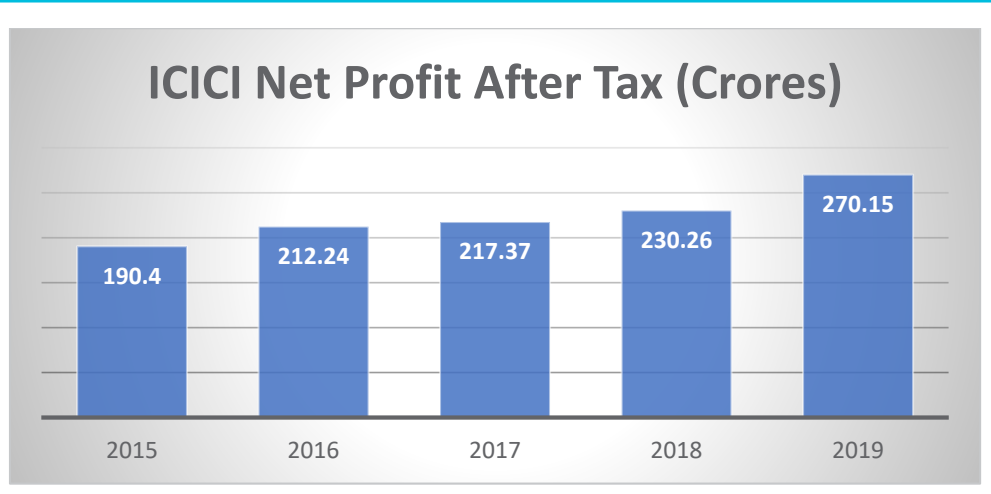

Figure 3: Net profit from 2015-2019 
best in improving the quality of the employees by giving them training on a regular basis for making them aware of the recent changes and help them to learn which can help their work easy and help them to serve the customer at their best. The impact of the training and development can clearly be seen in the net profit after tax of both the banks. Training and development is just a factor which affect the performance of the employees, there are many other factors which are also there but training and development is considered to be one of the important factor.

\section{Public Sector Banks considered - State Bank of India and Punjab National Bank:-}

In the public sector context, State Bank of India - SBI is an Indian multinational public sector bank, having its headquarters in Mumbai, Maharashtra. It is the largest bank in India with a $25.50 \%$ market share. Now to have this kind of capture in the market and to retain it is not an easy job for an organization. Human aspect plays an important part for achieving this goal. So SBI goes on a regular basis training of its employees throughout the country.

With the change in the environment in the banking sector, SBI has revamped its training system recently. SBI has now a total of 60 training institute spread across the country which train around 4200 employees per day. Under the new training system, the bank will be reskilling their 2.60 lakh employees through customised role-based certifications and this is only related to the general development of employees. Apart from this, the bank has focused on specialisation as well, SBI have started their six Apex Training Institutes (ATIs) at Hyderabad, Kolkata, Gurugram and Indore centres which deals only into domain specific training to the employees. SBI have also entered into partnership with two executive education providing institutes for rolling out co-branded Leadership Development programmes for top level executives, at State Bank Institute of Leadership (SBIL), Kolkata, which will be a flagship institute for training top executives in the BFSI sector. So different types of training conducted by SBI for the employees are as follows:-

- $\quad$ On-site Training- The program has been introduced at metropolitan and urban city centres in identified critical branches as well as for critical market segments. It is meant as a support to the institutional training to meet branch specific and desk specific training needs of employees. The training in On-site is imparted by a visiting faculty appointed by the bank.

- In branch training forum-It is an intra-branch training forum formed on a voluntary basis. The forum is headed by the Branch Manager, with him 2 to 3 officers and few senior awarded staff members are its other members. The main purpose of this forum is to identify knowledge gap of the employees in the branch and discuss the same with others at a monthly meetings and suggest remedial measures. It is a mechanism for improving efficiency and productivity at branches on voluntary basis.

- $\quad$ E-Learning- SBI has also introduced the concept of E-learning for the training of employees in the organization. They have introduced an internet web based e-leaming system on a "Hosting Model" approach administered by the Apex Training Institutes of the Bank to enable staff at branches and other offices to access training contents hosted by the Bank on the servers of suitable solution provider.

- Workshop on Human values- State bank of India on a regular basis DGM/GMs and CGMs to IIM Kolkata, for the programmes which is conducted in two phases of 3 days each on human values. The objective of the program is to help the employees improve in the decision making process, Restoring purity in mind, holism and in the individual and then in the organization, value free professional management and its consequences in the long run.

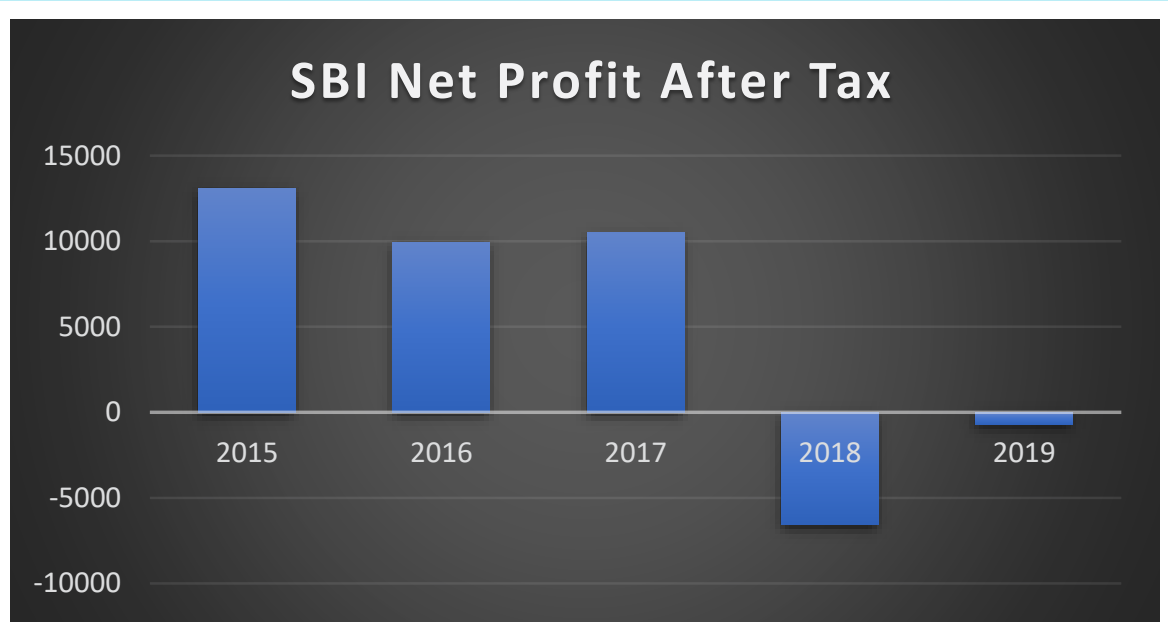

Figure 4: Net profit from 2015-2019 


\section{- Programme conducted by external agencies at the} bank's training centres- External agencies or consultants help is taken for conducting special programmes on Information Technology, Personal Effectiveness, Administration, and Technology Up-gradation at bank's staff training centres for which prior approval of the Corporate Centre and Circle Management is obtained.

So it is clear from the above discussion that SBI is well aware of the changing business environment in the economy and to deal with that they are spending a huge amount of money on the training and development of the employees in SBI by different ways and methods available in the market. Now let's have a look into the financial performance SBI from 2015 to 2019 in the form of a bar graph showing the net profit after tax.

The results of SBI are a shock after seeing the training and development by SBI for the employees. We can say that they are blindly investing huge sum of money on the training program of the employees, but are not able to get result out of it. So they need to look into this matter as soon as possible before it causes severe damage to the organization. Training of employees will have a significant impact on the performance of the organization; it is true for all enterprise. Hence, it cannot be said that they are just conducting training programs just for the sake of doing it. There are other factors as well which impact the overall performance of the organization, but surely they have to look into the matter as the valuable funds of the company are just being wasted on the training and development of the employees Perhaps they need to make some changes if need be so that training initiatives impact the performance of employees positively and help the organization grow and expand in long run.

The other public bank chosen for the study is Punjab National Bank (PNB). Punjab National bank is a banking and financial service bank which is owned by government of India.
The bank was founded in the year 1894 and it's headquarter is in Delhi, India. As of June 2019, the bank has around 7036 branches and 8906 ATMs across India. In terms of market share this is the 4th largest bank operating in the Indian market. Now let's have a look into different training and development programmes undertaken by the management of PNB for the development of the employees, so that they can survive in this competitive market. An important part of, PNB bank is that they believe in the knowledge up-gradation and development of the employees in the organization, PNB BANK Academy, which was previously known as Institute of Management Development, has an ISO 9001 certification, along with 7 other training institutes, play a key role in keeping their workforce at pace with global standards. The training methods followed in PNB are as follows:-

- Management Training program by PNB- This type of training programme are for the existing employees in the organization. The purpose of this type of training is to expose the employees to the various programme which plays an important role in their day to day operations. The type of training in under this process are principles of Management, corporate planning, project management, management of change, management of technology, team building and conflict resolution. The executives of E-4 and above levels are exposed to General Management Training in reputed Institutions including ASCI \& IIM's to achieve the best results.

- $\quad$ Sponsoring Executives and employees for higher studies in India and Abroad- This programme is undertaken by PNB just to improve the quality of the employees in the organization by encouraging them to go for higher studies in India or Abroad. There are certain criteria which the employees must fulfil to get eligible for this programme which is clearly stated by PNB in their manuals. This type of training programme benefits both employees and the organization, as the employees are coming back to the organization after completing their higher studies.

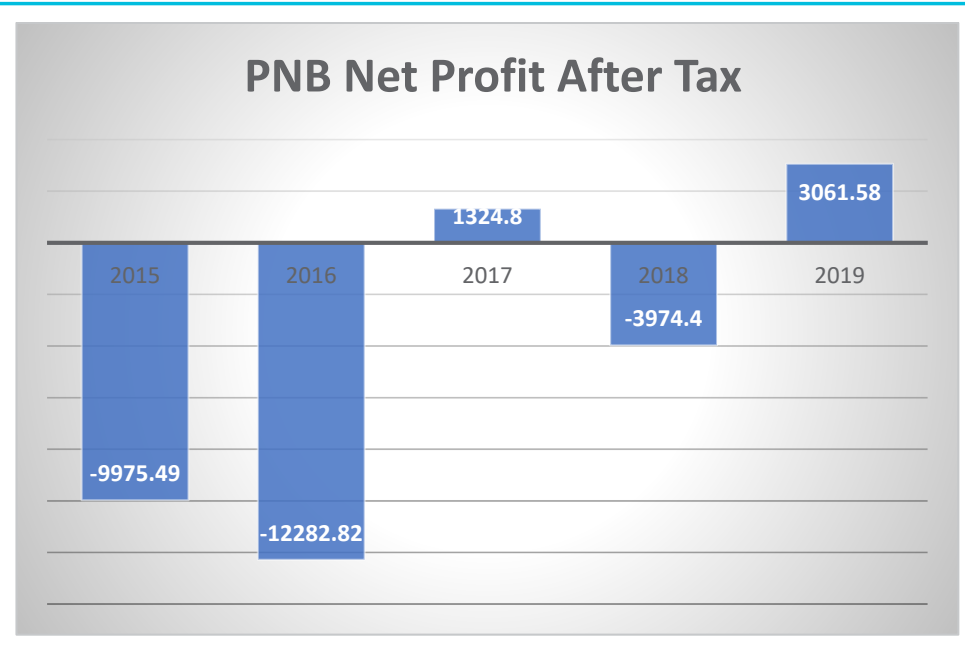

Figure 5: Net profit from 2015-2019 
From the above graph we can see that the bank is incurring a huge amount of losses in most of the years. This training and development is not the single factor that this is happening. In recent times, there have been some fraudulent activities which has been taking place in PNB which has caused a huge damage to the image of the company and along with that there is some part of poor training and development by the management of the bank. PNB is investing a huge amount of money on the training and development of employees on a year on year basis but there is something wrong which the management have to look into.

\section{Conclusion:}

To develop an integrated and a proactive training and development strategy there is a requirement of coherent corporate culture rather than ad-hoc programs. In a service oriented industry like banking, people are the most important assets and a bank must efficiently manage its employees during every phase of employment in this competitive environment. In spite of the challenges and difficulties that occurs in the training and development of the employees, banks still goes for the training of the employees, because they know what difference the training programme can create for the employees in the organization.

So now we have seen the training and development process which is undertaken by all the 4 banks in the Indian economy. All the banks give almost equal importance to the training and development of the employees, because they are well aware of the fact is how competitive the market is nowadays and how difficult it is for an organization to survive in this competitive market. A good training and development setup of an organization give the organization a competitive edge over its competitors in the market. After studying the training programme of all the 4 banks, there is a clear difference in the training of the employees in private and public bank. The difference is very basic, but in the current scenario it is the only element which is making the difference in the performance of the employees in the organization. The element which is making the difference is the use of technology in the training programmes by the public banks.

After a thorough study of the methods of public and private bank it is clear that public bank still gives importance on the traditional kind of raining to the employees that is classroom training to the employees, whether they are newly recruited or the existing employees. The other difference which is seen is that public bank has their own training institute all over India, where they provide training to the employees as well as the high level executives of the organization, it is known that for building this type of training institute, banks are getting funds directly from the government, but instead of this they can invest these funds in some other areas to improve their training programme so that they can compete with the privatised banks in India.
The other things that public banks can do is that they can start using modern technology for the training and development of the employees. Traditional training process is no doubt a good process but it is not helpful in all the situations. E-Learning is gaining its market share and it's been used by many organization in recent time. The process of E-Learning is simple and is beneficial for both, employees as well as for the organization. Instead of giving in-house training to the employees, they can hire a third party for providing the training, which will actually reduce the cost of the training of the employees. Training process does not end after imparting the training to the target group, but there should be a proper feedback session with the employees who have undergone the training programme. Private Banks take this feedback process seriously and make necessary changes after doing a proper analysis.

\section{"Live as if you were to die tomorrow. Learn as if you were to live forever."}

\section{-Mahatma Gandhi}

\section{References}

1. Amir Elnaga, A. I. (2013). The Effect of Training on Employee Performance. European Journal of Business and Management.

2. Berge, Z., Vermeil, M.D., Berge, N., Davis, L. and Smith, D. (2012) The Increasing Scope of Training and Development Competency.

3. Franklin Dang Kum, R. C. (2014). The Impact Of Training And Development On Employee Performance: A Case Study Of Escon Consulting. Singaporean Journal of Business Economics and Management Studies.

4. Mahbuba Sultana (2013).Impact of Training \& Development on the Performance of the Employees of Silk Bank Limited-Karachi East Division Branches.

5. Mani A \&Dr. Joy P.A. (2012). "Effectiveness of Training among bank employees: A Comparative Study of selected public and private sector banks in India”.IJRMEC Volume 2, Issue 7.

6. Muhammad FarhanAkhtar, (2011). The Impact of Training and Development on Employee Performance. IOSR Journal of Business and Management.

7. Muhammad Imran (2016). Impact of Training \& Development on Employees' Performance in Banks of Pakistan.European Journal of Training and Development Studies Vol.3.

8. Ray Chaudhuri, M. (2007) Employee Training: Grooming for a Better Tomorrow", reprint of the paper (earlier published in HRM Review, January 2004, ICFAI Press, Hyderabad) in "The ICFAI University Press on Training and Development: Perspectives from the Service Sector", edited by Sumati Reddy of ICFAI Books, Hyderabad, published by ICFAI Books, The ICFAI University Press, Hyderabad, First Edition 2007.

9. Ramakrishna et, al. (2012) Effectiveness of Training and Development Programmes- A Case Study Of Canara Bank Employees in Kurnool District. International Journal of Multidisciplinary Research. Vol.2.

10. Sing and Mohanty (2012). UK Manager's Conceptions of Training and Development. Journal of European Industrial Training.

11. https://v1.hdfcbank.com/htdocs/common/pdf/corporate/Annual Report_2018-19.pdf

12. https://www.icicibank.com/aboutus/annual.page

13. https://www.sbi.co.in/corporate/AR1819/download-annual-report.html 
Bearing of Training on Employee Performance: Evidence from the Banking Sector in India

14. https://www.pnbindia.in/annual-reports.html

15. https://www.moneycontrol.com/

Citation: Dr.Manodip Ray Chaudhuri, Mr.Parth Mehra "Bearing of Training on Employee Performance: Evidence from the Banking Sector in India."American Research Journal of Business and Management, vol 6, no. 1, 2020, pp. 1-10.

Copyright (C) 2020 Manodip Ray Chaudhuri, et al. This is an open access article distributed under the Creative Commons Attribution License, which permits unrestricted use, distribution, and reproduction in any medium, provided the original work is properly cited. 